\title{
Fatigue Analysis Section Employee Branch Production Line F3 Cold in PT. Asahimas Flat Glass, Tbk Jakarta
}

\author{
Prima Fithri ${ }^{1}$, Ikhwan Arief ${ }^{2}$, Lusi Susanti ${ }^{3}$, Ravi Darwin ${ }^{4}$ \\ primafithri@eng.unand.ac.id ${ }^{1}$, ikhwanarief@eng.unand.ac.id ${ }^{2}$, lusi@eng.unand.ac.id ${ }^{3}$, \\ ravi.darwin@gmail.com ${ }^{4}$ \\ Industrial Engineering, Faculty of Engineering, Universitas Andalas, Kampus Limau Manih Pauh \\ Padang 1,2,3,4
}

\begin{abstract}
Fatigue is a problem that should be given special attention, both formal and informal employment lead to fatigue. Fatigue or performance will degrade performance and increase errors in the work. The decline in performance is synonymous with reduced work productivity. Job satisfaction is also important in human resource management because it directly or indirectly affects the productivity of employees in an organization or company. This research is an analytic survey with a cross-sectional design to analyze the relationship between job fatigue and job satisfaction and employee productivity branch section production line F3 cold PT. Asahimas Flat Glass, Tbk Jakarta in 2018 with a sample of 25 people working. Measurement of job fatigue, job satisfaction and productivity of each using a questionnaire. Use KAUPK2 job fatigue, job satisfaction questionnaires job satisfaction, and measure job productivity by using questionnaire productivity. Results of research found that employees who feel tired as many as 6 people (40\%) and was not tired by $9(60 \%)$ against fatigue. An employee who are not satisfied as much as 7 people $(47 \%)$ and satisfied as much as 8 people (53\%) on job satisfaction. Employees who feel does inappropriate as many as 7 people (47\%) and job productivity appropriate to 8 people $(53 \%)$ on work productivity. Expected to be made empirically more of factors that affect work productivity and satisfaction factors other than fatigue.
\end{abstract}

Keywords: Fatigue, Satisfaction, Productivity, Employee

\section{Introduction}

PT. Asahimas Flat Glass, Tbk is a pioneer in a glass manufacturing company making once the Reviews largest in Indonesia. PT. Asahimas Flat Glass, Tbk capable of producing glass of 270,000 tons/year. Glass production process is currently only done on the production line for production line F3 F4 has been moved to Cikampek. Production line F3 has two parts items, namely HOT and COLD roommates have different functions. On the production line, HOT F3 is a mixing place throughout the glass material, the process of melting, and drawing that has a very high temperature. Whereas in F3 COLD production line is where the process of cutting and packaging of glass the which has a much lower temperature than the production line F3 HOT.

One part of the production line is part COLD Branch F3. At the Branch is a parts distributor, amounting to one person and pick up the glass, amounting to 2 or 4 by the thickness of the work 
produced. The task is to encourage the distributor section of glass that has been cut by the machine to pick up part of a predetermined size by special gloves that exposed a sheet of glass is not the which can lead to injury. The task is part of pick receives a sheet of glass from the distributor, lifting and placing a glass sheet on a pallet or box has been provided by using special gloves so as not to hit the glass sheet the which can lead to injury as well.

Work performed at the Branch just doing repetitive or monotonous. At the distributor just push the glass in slow motion so the glass does not fall when the part pick-up receives the glass with the body bent and so Also on the pick up that lifts the glass and insert the glass into the pallet or box with bending your body that can result in injury on the backs of employees.

Conducted a study on the relationship job Fatigue and job satisfaction and productivity of nurses in the inpatient unit RSU. Dr. Tengku Mansyur Tanjung Balai. This study suggests that fatigue is a problem the which should receive attention for all types of formal and informal job cause fatigue. Fatigue can degrade performance and increase job error. The reduced performance is tantamount to lower job productivity. Also, Job satisfaction is an important target in human resource management because it directly or indirectly affects work productivity in an organization or company.[5]

Circumstances were a quite noisy work environment, the temperature is hot enough, and poor ventilation. An initial survey in this section can be concluded that employees in this section is less focused on the work and can reduce work productivity, employees are encouraged. Therefore fatigue analysis using questionnaires to measure fatigue levels, satisfaction, and work productivity by using Fatigue Feelings Questionnaire Measure Tool Works (KAUPK2).

According to the explanation on the above background, it can be Formulated the problem in this research is how to Determine the percentage of job Fatigue and job satisfaction on employee productivity branch section F3 cold production line based Questionnaire Measuring Fatigue Feelings of Work (KAUPK2).

The research objectives are to determine the percentage tired and not tired of the employees of the branch who experienced job Fatigue based questionnaire measuring tools work feeling (KAUPK2), determine the percentage of satisfied and dissatisfied with the branch employee who experiences job satisfaction based on job satisfaction questionnaire, and determine the Appropriate percentage amount and does not Correspond to the employees of the branch that is experiencing job productivity, job productivity based questionnaire.

Limitation of problems in this research are employees who were respondents in this study were employees of the branch production line F3 cold and work that produces glass with a thickness of $2 \mathrm{~mm}$.

\section{Method}

Research design using observational analytic type , cross sectional approaching method. The collection of the data is a stage all the data needed to solve a problem raised. There are primaries of data and secondary data. Primary data obtained from interviews conducted with employees about the inner workings of information fatigue branch cold production line F3 PT. Asahimas Flat Glass, Tbk. Secondary data is the data requested from the branch F3 cold production line in the form of the number of employees by 25 people and the number of shifts.

General Data section consists of a branch employee in one day and days of work for one year. Here is an employee time data in a single day and days of work for one year. Time employees work in one day: 8 hours. The number of working days during one year: 251 days 
PT Asahimas Flat Glass, Tbk have Reviewed their share of work schedule consists of three parts items, namely the morning shift, afternoon, and evening. With the 2-2-2 shift rotation system with division of job hours each shift items, namely;

a. Morning Shift: $07.00-15.00$

b. Afternoon Shift: 15:00 - 23:00

c. Night shift: 23:00 - 07:00

Worker resting period is divided branch section 4 periods. Workers will work for 100 minutes, then given a break for 20 minutes, and continued until work ends.

\section{Results}

The data obtained are then processed to obtain the percentage of respondent characteristics, work exhaustion, job satisfaction, and work productivity. The number of respondents who participated in this study as many as 15 people. Distribution by age group, gender, marital status, length of employment and salary/wages can be seen as follows:

Table 1. Frequency Distribution Characteristics of Respondents Section Branch Line Productions F3 COLD PT. Asahimas Flat Glass, Tbk in 2018.

\begin{tabular}{|c|c|c|c|c|c|}
\hline \multicolumn{6}{|c|}{$\mathrm{AGE}$} \\
\hline & & Frequency & Precent & Valid Precent & Cumulative Precent \\
\hline \multicolumn{2}{|c|}{$18-22$ Years Old } & 4 & $26,7 \%$ & $26,7 \%$ & $26,7 \%$ \\
\hline \multicolumn{2}{|c|}{$23-27$ Years Old } & 5 & $33,3 \%$ & $33,3 \%$ & $60,0 \%$ \\
\hline \multicolumn{2}{|c|}{$28-32$ Years Old } & 4 & $26,7 \%$ & $26,7 \%$ & $86,7 \%$ \\
\hline \multicolumn{2}{|c|}{33 - 37 Years Old } & 2 & $13,3 \%$ & $13,3 \%$ & $100,0 \%$ \\
\hline \multicolumn{2}{|c|}{ Total } & 15 & $100 \%$ & $100 \%$ & \\
\hline \multicolumn{6}{|c|}{ SEX } \\
\hline & & Frequency & Precent & Valid Precent & Cumulative Precent \\
\hline \multirow{3}{*}{ VALID } & Man & 15 & $100 \%$ & $100 \%$ & $100 \%$ \\
\hline & Woman & 0 & $0 \%$ & $0 \%$ & $100 \%$ \\
\hline & Total & 15 & $100 \%$ & $100 \%$ & \\
\hline \multicolumn{6}{|c|}{ MARITAL STATUS } \\
\hline & & Frequency & Precent & Valid Precent & Cumulative Precent \\
\hline \multirow{3}{*}{ VALID } & Married & 7 & $47 \%$ & $47 \%$ & $47 \%$ \\
\hline & Not Married & 8 & $53 \%$ & $53 \%$ & $100 \%$ \\
\hline & Total & 15 & $100 \%$ & $100 \%$ & \\
\hline \multicolumn{6}{|c|}{ YEARS OF SERVICE } \\
\hline & & Frequency & Precent & Valid Precent & Cumulative Precent \\
\hline \multirow{3}{*}{ VALID } & $<5$ Years & 13 & $87 \%$ & $87 \%$ & $87 \%$ \\
\hline & $>5$ Years & 2 & $13 \%$ & $13 \%$ & $100 \%$ \\
\hline & Total & 15 & $100 \%$ & $100 \%$ & \\
\hline
\end{tabular}




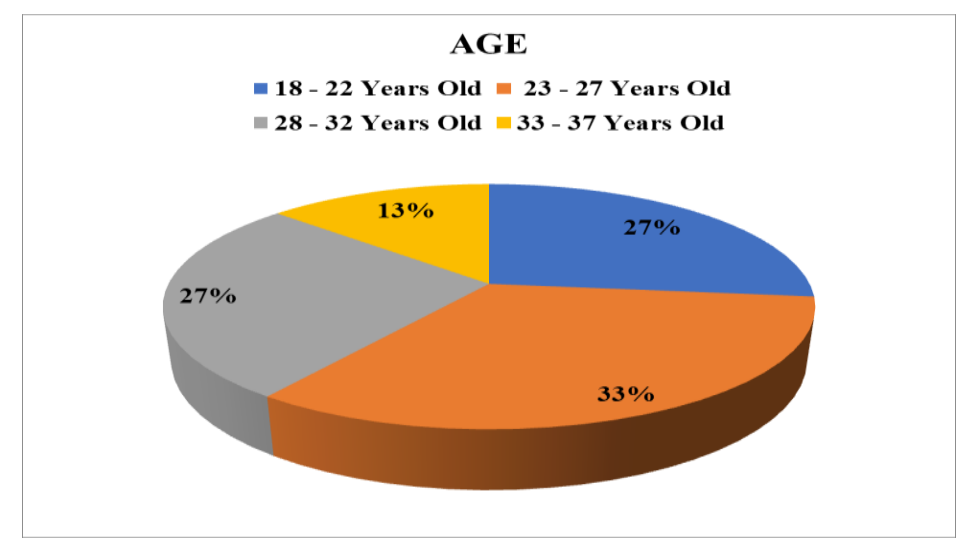

Figure 1. Frequency Distribution Age of Respondents Section Branch Line Productions F3 COLD PT. Asahimas Flat Glass, Tbk in 2018.

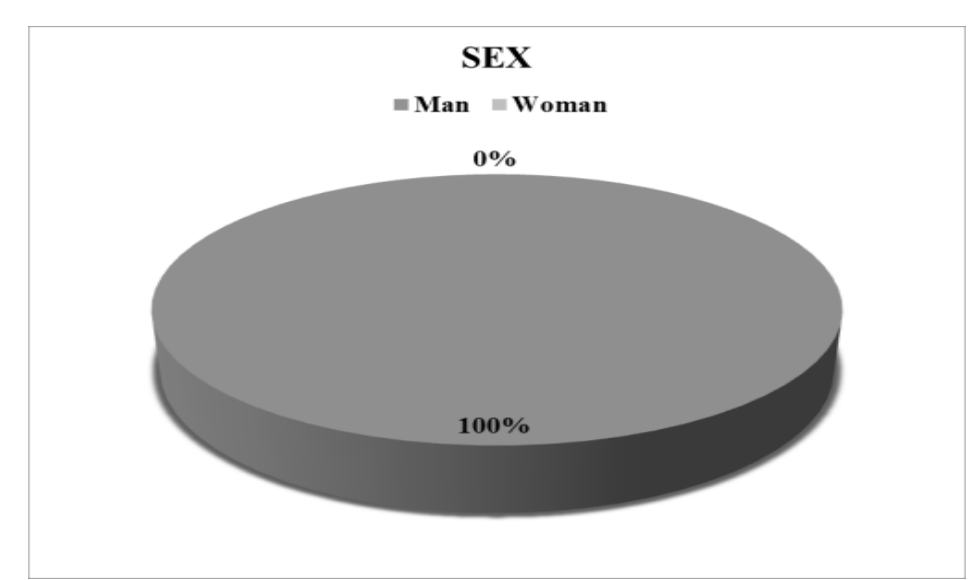

Figure 2. Frequency Distribution Sex of Respondents Section Branch Line Productions F3 COLD PT. Asahimas Flat Glass, Tbk in 2018.

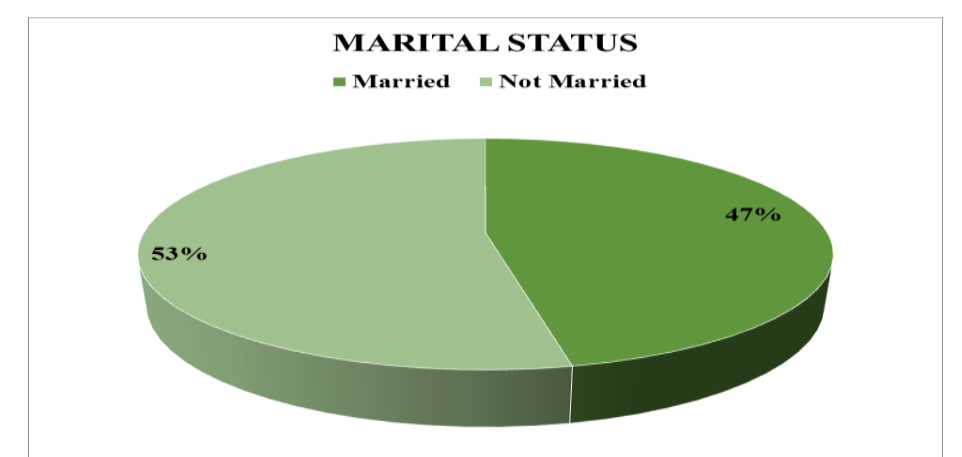

Figure 3. Frequency Distribution Marital Status of Respondents Section Branch Line Productions F3 COLD PT. Asahimas Flat Glass, Tbk in 2018. 


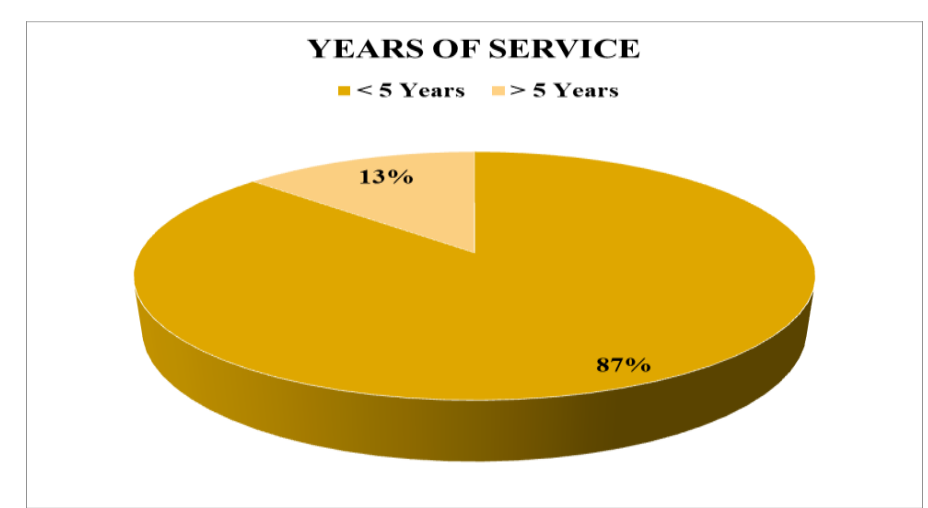

Figure 4. Frequency Distribution Years Of Service of Respondents Section Branch Line Productions F3 COLD PT. Asahimas Flat Glass, Tbk in 2018.

Table 1 above shows the production line at the branch F3 cold PT Asahimas Flat Glass Tbk most respondents in the age category is the age of 23-27 years is 5 people $(33.3 \%)$. Based on the categories of gender, all employees of the branch section Sexes - download as many as 15 people $(100 \%)$. Based on the categories of marital status, the worker more unmarried status of 8 people $(53 \%)$. Based on the categories of employment, the worker more tenure $<5$ years as many as 13 people $(87 \%)$.

Based on interviews with questionnaire KAUPK2 to workers part branch cold production line F3 PT Asahimas Flat Glass, Tbk the respondent's feelings about work fatigue can be seen in table 2 below.

Table 2. Distribution of Respondents by Job Fatigue in Section Branch Line Productions F3 COLD PT. Asahimas Flat Glass, Tbk in 2018.

\begin{tabular}{|c|c|c|c|}
\hline No. & Job Fatigue & Frequency & $(\%)$ \\
\hline 1 & Fatigue & 9 & $60 \%$ \\
\hline 2 & Unfatigue & 6 & $40 \%$ \\
\hline \multicolumn{2}{|c|}{ Total } & 15 & \multicolumn{2}{c|}{$100 \%$} \\
\hline
\end{tabular}

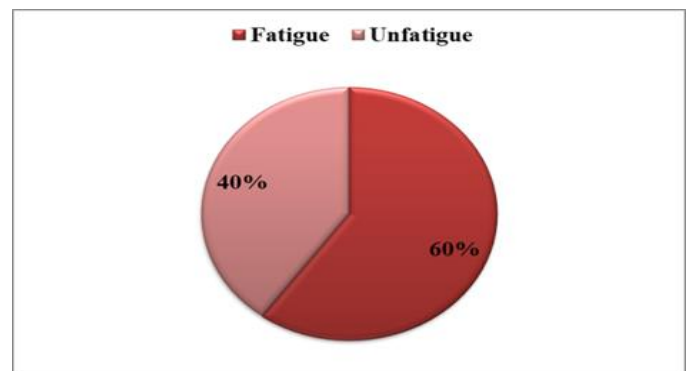

Figure 5. Distribution of Respondents by Job Fatigue in Section Branch Line Productions F3 COLD PT. Asahimas Flat Glass, Tbk in 2018. 
From Table 1.2 above shows the production line at the branch F3 cold PT. Asahimas Flat Glass, Tbk highest number of respondents based on the state Fatigue Work is not exhausted that $9(60 \%)$. Based on the results of interviews using job satisfaction questionnaire to workers part branch production line F3 cold PT Asahimas Flat Glass Tbk then Obtained respondent satisfaction related to Reviews their interests, tranquility, contact with fellow workers and Superiors, working time, work environment, salary, and promotion. Results can be seen in table 3 below:

Table 3. Distribution of Respondents by Job Satisfaction in Section Branch Line Productions F3 COLD PT. Asahimas Flat Glass, Tbk in 2018.

\begin{tabular}{|c|c|c|c|}
\hline No. & Job Satisfaction & Frequency & $(\%)$ \\
\hline 1 & Satisfaction & 8 & $53 \%$ \\
\hline 2 & Unsatisfaction & 7 & $47 \%$ \\
\hline \multicolumn{2}{|c|}{ Total } & 15 & $100 \%$ \\
\hline
\end{tabular}

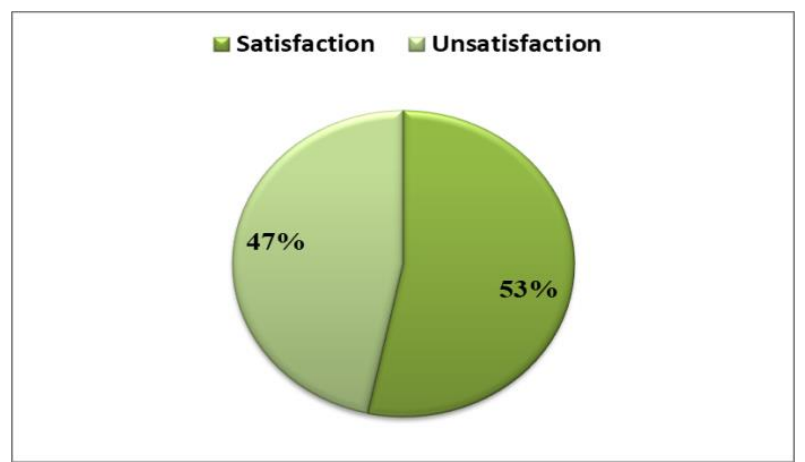

Figure 6. Distribution of Respondents by Job Satisfaction in Section Branch Line Productions F3 COLD PT. Asahimas Flat Glass, Tbk in 2018.

From Table 1.3 above shows, the production line at the branch F3 cold PT. Asahimas Flat Glass, Tbk highest number of respondents by job satisfaction items, namely the circumstances are satisfied items, namely $8(53 \%)$.

Based on the results of interviews using job satisfaction questionnaire to workers part branch production line F3 cold PT. Asahimas Flat Glass, Tbk then obtained respondent satisfaction related to reviews their interests, tranquility, contact with fellow workers and Superiors, working time, work environment, salary, and promotion. Measuring the level of job productivity in the study conducted by questionnaire respondents, ie productivity to $\mathrm{C}$ shift foreman at the branch production line F3 cold PT. Asahimas Flat Glass, Tbk. Results can be seen in Table 4 below:

Table 4. Distribution of Respondents by Work Productivity in Section Branch Line Productions F3 COLD PT. Asahimas Flat Glass, Tbk in 2018.

\begin{tabular}{|c|c|c|c|}
\hline No. & Job Productivity & Frequency & $(\%)$ \\
\hline 1 & Appropriate & 8 & $53 \%$ \\
\hline 2 & Unappropriate & 7 & $47 \%$ \\
\hline \multicolumn{2}{|c|}{ Total } & 15 & $100 \%$ \\
\hline
\end{tabular}




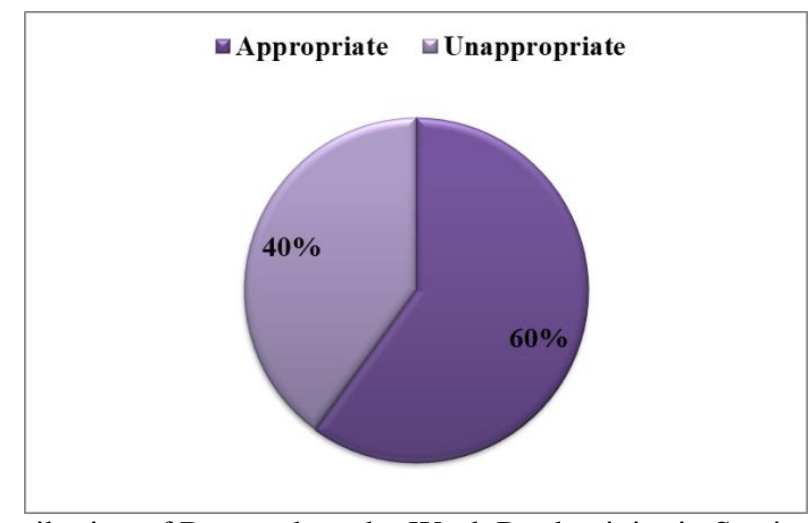

Figure 7. Distribution of Respondents by Work Productivity in Section Branch Line Productions F3 COLD PT. Asahimas Flat Glass, Tbk in 2018.

From Table 1.4 above shows the production line at the branch F3 cold PT. Asahimas Flat Glass, Tbk highest number of respondents based Work Productivity is the Appropriate circumstances items, namely 8 (53\%).

\section{Discussion}

Based on the results obtained in Table 1 of the age category at the branch F3 cold production line, the reviews largest age category is the age group 23-27 years is five people (33.3\%). It can be seen that the age of the respondents is of childbearing age (15-64 years according to the category of the National Development Planning Agency) that can reproduce. The results of the gender category in the branch F3 cold production line, all employees of the sexes - men who numbered as many as 15 people. Due to the branch is a job that is quite heavy and monotonous, the sexes - men suitable to do the job and be also seen on the physical condition of men are stronger than women. The results of the marital status category F3 on the production line of a cold branch, most categories are not married status of 8 people $(53 \%)$.

Based on Table 2 it can be seen feeling tired from research using questionnaires Measuring feeling Fatigue Work (KAUPK2) on the branch production line F3 cold, workers who feel tired as many as six people (40\%) and workers who feel tired as many as 9 people $(60 \%)$. It is known that workers who are experiencing feelings of fatigue in the category are not tired. Due to the workload at the branch are not heavy, work that is not varied, and the nature of work growing niche to be monotonous.

Value fatigue derived from using questionnaires Measuring feeling Fatigue Work (KAUPK2) can be seen from Table 3 only one statement that more than half of respondents said they were tired of feeling tired all over the body by 10 people $(67 \%)$ due to work using all the limbs, monotonous and repetitive.

Based on Table 3 it can be seen on the job satisfaction F3 branch cold production line, workers were satisfied as much as 8 people $(53 \%)$ and workers who are not satisfied as much as 7 people $(47 \%)$. 
The value of job satisfaction based on the information in Table 3.4 can be seen below the respondents are not satisfied with the company's attention to the possibility of the emergence of danger as many as 8 people (53\%). HSE should conduct an evaluation or review of the possibility of a danger so that the workers are calm in carrying out work, and there is rapid handling in the event of a danger that befalls workers. Furthermore, respondents were dissatisfied with the condition of the room temperature in the workplace as many as 9 people $(60 \%)$. Because when doing research it is true that the temperature in the room where the branch works is quite hot which can disturb the concentration of workers, and feel less comfortable when doing work. Furthermore, respondents were dissatisfied with the suitability of the air ventilation in the factory as many as 8 people $(53 \%)$. When conducting research, it is proven by direct observation that the air vents in the working area are inadequate because the working area is very wide. Which can cause minimal or lack of air change from outside the room into the room. The company should add air ventilation or provide air filter equipment. Furthermore, respondents were dissatisfied with the opportunity to obtain education, skills / abilities in work as many as 8 people (53\%). The company should provide the opportunity for workers to take higher education so that workers can add knowledge and insight and workers have the opportunity to rise in rank.

Based on Table 4 it can be seen on the job satisfaction F3 branch cold production line, Based on the questionnaire given to the branch foreman, the workers are mostly in appropriate with their duties according to the foreman.

After the analysis of the causes of fatigue are obtained in the production line F3 branch cold. Based on the fishbone diagram is caused by human factors, machine, method, and environment. The human factor is the employees feel tired throughout the body due to employees' lack of rest, temporary room conditions of work due to bad ventilation, and reach target due to less spirit of work - the next factor noisy engine due to the age-old machine. The next factor is the employees working methods roommates makeup employees can quickly intervening bored monotonous. The last, the summer due to environmental factors are less ventilation.

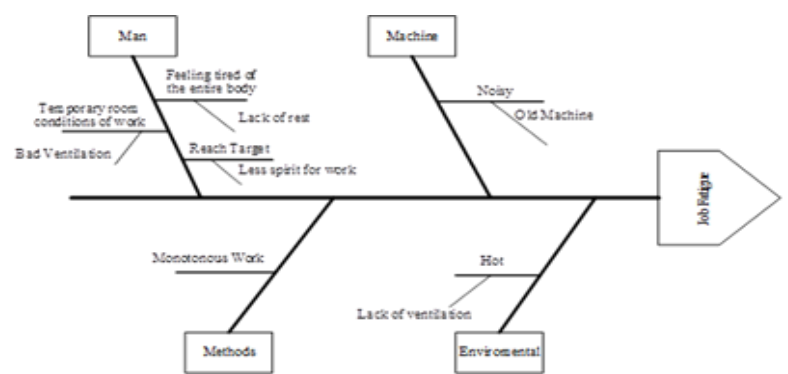

Figure 8. Fishbone Diagram

\section{Conclusion}

The conclusion of the settlement of case studies carried out is: of the 15 respondents, by age group most that the age group 23-27 years as many people (33.3\%). By sex, the most are men men of 15 people $(100 \%)$. Based on marital status at most that neither marries items, namely 8 $(53 \%)$. Based on years of service at most that work $<5$ years as many as 13 people $(87 \%)$. Beside that worker who feel tired as many as six people (40\%) and was not tired by 9 people $(60 \%)$. 
And Workers who are not satisfied as much as 7 people (47\%) and satisfied as much as 8 people $(53 \%)$, Work productivity does not fit as many as 7 people $(47 \%)$ and job productivity according to 8 people $(53 \%)$.

\section{References}

[1] As'ad, S.U. 1999. Seri Ilmu dan Sumber Daya Manusia, PSIKOLOGI INDUSTRI. Penerbit Liberty Yogyakarta. Yogyakarta

[2] Notoatmodjo, S. 1997. Ilmu Kesehatan Masyarakat Prinsip-Prinsip Dasar, Jakarta: Rineka Cipta.Isnani, Murul. (2013). Analisis Perhitungan Harga Pokok Produksi Dalam Menetapkan Harga Jual Beton Pada Pt Indo Beton Palembang. Jurnal.

[3] Sinugan M. 2008. Produktivitas Apa dan Bagaimana. Bumi Aksara. Jakarta

[4] Suma'mur. 1996. Higiene Perusahaan dan Kesehatan Kerja. Gunung Agung. Jakarta

[5] Tarwaka, Bakri S.H.A, dan Sudiajeng L. 2004. Ergonomi Untuk Keselamatan, Kesehatan Kerja dan Produktivitas. UNIBA PRESS: Surakarta.

[6] Wignjosoebroto. S. 2003. Ergonomi, Studi Gerak dan Waktu Teknik Analisis untuk Peningkatan Produktivitas Kerja. Edisi I cetakan kedua, Penerbit Guna Widya. Surabaya

[7] Yusdarli. 2010. Hubungan Kelelahan Kerja dan Kepuasan Kerja dengan Produktivitas Kerja Perawat di Ruang Rawat Inap RSU Dr. Tengku Mansyur TanjungBalai. Medan : Fakultas Kesehatan Masyarakat. Universitas Sumatera Utara. 